Hamer, T. E., K. Nelson, J. Jones, and J. Verschuyl. 2021. Marbled Murrelet nest site selection at three fine spatial scales. Avian Conservation and Ecology 16(2):4. https://doi.org/10.5751/ACE-01883-160204

Copyright (C) 2021 by the author(s). Published here under license by the Resilience Alliance.

Research Paper

\title{
Marbled Murrelet nest site selection at three fine spatial scales
}

Thomas E. Hamer ${ }^{1}$, Kim Nelson ${ }^{2}$, Jay Jones ${ }^{3}$ and Jake Verschuyl ${ }^{4}$

${ }^{1}$ Hamer Environmental, ${ }^{2}$ Oregon State University, Department of Fisheries and Wildlife, Corvallis OR, ${ }^{3}$ Weyerhaeuser Company, Seattle, WA, ${ }^{4}$ National Council for Air and Stream Improvement

\begin{abstract}
We implemented a unique tree-climbing effort to examine nesting-habitat selection of Marbled Murrelets (Brachyramphus marmoratus) in managed forest stands of Washington and Oregon during 1996-1999. Researchers climbed over 3000 trees to search for old and active murrelet nests during the breeding season (May-Sept.) in a random sample of stands known to be occupied by murrelets. Within these stands, characteristics of murrelet nest sites and non-nest sites were measured at three fine spatial scales: nest limb or platform, nest tree, and nest-site or forest patch (0.5 ha). We report results of a Bayesian hierarchical logistic regression model using three covariates at each of the three fine spatial scales. All three branch/platform scale covariates positively predicted nest occupancy with higher probabilities of nesting occurring at branches/platforms with higher horizontal cover, larger platform diameters, and higher moss cover. Tree scale characteristics associated with higher probabilities of nesting included higher platform counts and higher moss depth. Effect of tree diameter on probability of nesting was unclear. At the patch scale, lower probability of nesting occurred for stands with higher densities of trees with platforms. This unexpected relationship may be due in part to decreasing likelihood of observing a nest on a given platform when there are more platforms in a patch. Variation in tree size and percent canopy cover at the patch scale showed no clear association with nest selection at the patch scale. The prevalence of nests in Dwarf Mistletoe-infected hemlock trees may have partially obfuscated the effect of tree diameter on probability of encountering a nest in portions of our study area. Fine scale conservation efforts for Marbled Murrelets may include recruiting or retaining trees with larger numbers of platforms, large branches with high percentages of moss cover and horizontal cover, and younger trees with platforms created by Dwarf Mistletoe deformities.
\end{abstract}

\section{Sélection des sites de nidification du Guillemot marbré à trois échelles spatiales fines}

RÉSUMÉ. Nous avons déployé beaucoup d'effort pour grimper aux arbres afin d'examiner la sélection des habitats de nidification des Guillemots marbrés (Brachyramphus marmoratus) dans les peuplements forestiers aménagés de l'État de Washington et de l'Oregon de 1996 à 1999. Les investigateurs ont grimpé dans plus de 3000 arbres pour chercher des nids de guillemots, abandonnés ou actifs, pendant la saison de nidification (mai-sept) selon un échantillonnage aléatoire de peuplements connus pour être occupés par des guillemots. Dans ces peuplements, les caractéristiques des sites de nidification ou de non-nidification des guillemots ont été mesurées à trois échelles spatiales fines : branche ou plateforme de nidification, arbre de nidification et site de nidification ou îlot forestier $(0,5$ ha). Nous présentons les résultats d'un modèle de régression logistique hiérarchique bayésien incorporant trois covariables à chacune des trois échelles. Les trois covariables à l'échelle de la branche/plateforme ont prédit positivement l'occupation des nids, la probabilité la plus élevée de nidification à cette échelle s'avérant être en présence d'un couvert horizontal plus élevé, d'un diamètre de plateforme plus grand et d'un couvert de mousses plus important. À l'échelle de l'arbre, les caractéristiques associées à une probabilité plus élevée de nidification comprenaient un nombre plus élevé de plateformes et une plus grande épaisseur de mousses. L'effet du diamètre des arbres sur la probabilité de nidification était incertain. À l'échelle de l'îlot, la probabilité de nidification était plus faible dans les peuplements présentant une plus grande densité d'arbres avec des plateformes. Cette relation inattendue peut être en partie explicable à la diminution de la probabilité d'observer un nid sur une plateforme donnée lorsqu'il y a plus de plateformes dans l'îlot. La variabilité de la taille des arbres et du pourcentage de couvert forestier à l'échelle de l'îlot n'a pas permis d'obtenir une association nette de la sélection des nids à cette échelle. La fréquence plus élevée de nids dans les pruches attaquées par le faux-gui peut avoir partiellement masqué l'effet du diamètre des arbres sur la probabilité de trouver un nid dans certaines parties de notre zone d'étude. Les activités de conservation à l'échelle fine destinées aux Guillemots marbrés devraient comprendre le recrutement ou la conservation d'arbres ayant un plus grand nombre de plateformes, de grosses branches au pourcentage élevé de couvert de mousses et de couvert horizontal, et d'arbres plus jeunes ayant des plateformes issues de déformations causées par le faux-gui.

Key Words: Brachyramphus marmoratus; forest management; habitat selection; Marbled Murrelet; nest-site characteristics; nesting ecology; Oregon; tree climbing; Washington 


\section{INTRODUCTION}

Knowledge of a species' habitat preferences is crucial for designing management plans to maintain populations. Understanding influence of forest characteristics on nest site selection will benefit efforts aimed at recruiting or improving habitat for specific species. In the case of the Marbled Murrelet (Brachyramphus marmoratus; hereafter, murrelet), a small and unique member of the family Alcidae, an increased understanding of the forest characteristics influencing nest site selection has the potential to improve efficacy of forest management-related conservation measures. The murrelet was listed as threatened (provincially and federally) south of its Alaska breeding range in 1990 and 1992, respectively (USFWS 1992, COSEWIC 2012). Populations are thought to have declined from historic numbers, primarily as a result of reductions in old-growth forest nesting habitat from logging and development in coastal areas (McShane et al. 2004, USFWS 2009, RIT 2012).

Murrelets are secretive nesters (Nelson and Hamer 1995a). Unlike other members of the Alcidae family that nest colonially on islands or cliffs, murrelets nest in trees and in low densities in older aged coniferous forests (Hamer and Nelson 1995, Nelson 2020). Because they do not construct a nest, presence of potential nest platforms created by large or deformed tree branches (including mistletoe) with moss or other substrate are key habitat attributes (Hamer 1995, Burger 2002, McShane et al. 2004, Nelson et al. 2006). Although forest characteristics associated with murrelet nesting have been described previously, most efforts have focused on forest stand or patch (sub-stand) scales (e.g., Grenier and Nelson 1995, Hamer and Nelson 1995, Baker et al. 2006, Hamer et al. 2008, Waterhouse et al. 2011, Wilk et al. 2016). The size of forest patches (sample areas) measured in these studies varied from 0.2 to 3 ha. Thus, relatively little information exists on nesting habitat selection at finer spatial scales immediately around nest trees $(\leq 0.02 \mathrm{ha})$, and at the tree and platform scales, because nest sites are extremely difficult to locate (Nelson and Hamer 1995a).

No study has examined murrelet nest selection at three scales simultaneously thereby addressing partial confounding among covariates at different scales. One radio-telemetry study examined the difference between successful versus unsuccessful nests (Bradley 2002) at a landscape scale. Although landscape scale habitat data may be easier to obtain, landscape-only models received less support compared with models that incorporated patch scale variables measured from the ground (Silvergieter and Lank 2011a). Several other habitat preference studies used number of murrelet detections from ground surveys to make comparisons at the stand scale (Miller and Ralph 1995, Bahn and Newsom 2002, Burger and Bahn 2004, COSEWIC 2012). Others compared occupied and unoccupied sites based on presence or absence of audio-visual detections of murrelets (Hamer 1995, Meyer et al. 2004) or nest trees to platform trees at the forest patch scale (Silvergieter and Lank 2011b). Golightly et al. (2009), in northern California, compared habitat differences between successful and unsuccessful nests at the nest, tree, and stand scales, but they had a sample of only 10 nest sites.

Studies that examined murrelet habitat preferences at smaller scales were only able to offer comparisons of known nest sites to random sites, without verification that murrelets had not nested at random sites (Baker et al. 2006, Golightly et al. 2009, Silvergieter and Lank 2011a, b, Wilk et al. 2016). Verification is difficult because the only way to be certain that a forest patch or tree was not used for nesting is to climb all trees at a random site and inspect each branch or deformity for evidence of nesting. In this paper, we refer to this approach as intensive tree climbing. Only one study (Conroy et al. 2002) made the effort to confirm unused sites ( 0.07 ha scale) in forest patches. However, Conroy et al. (2002) located only five nests, thus comparisons were limited.

Our goal was to examine murrelet nest-site selection at three fine scales simultaneously using a random sampling approach and intensive tree climbing in known occupied stands in western Washington and Oregon, USA. Specifically, our objectives were to determine if characteristics of nest platforms, nest trees, and the surrounding forest structure at nest sites ( 0.2 ha patch) differed from random sampled platforms, trees, and patches without nests. Our analysis focused on metrics of forest structure at platform, tree, and patch scales that have previously been linked to murrelet nesting. The three-scale approach also allowed for comparison of the strength of covariates at different scales in driving the probability of finding a murrelet nest on a given platform $[\mathrm{Pr}$ (nest)].

\section{METHODS}

\section{Study area}

Sampling occurred on the Olympic Peninsula in Washington and the Oregon Coast Range. In Washington, we focused our tree climbing on private and state lands on the western and northern Olympic Peninsula in the western hemlock (Tsuga heterophylla) and silver fir (Abies amabilis) zones (Franklin and Dyrness 1973). In Oregon, our study focused on managed Oregon Department of Forestry lands in the western hemlock and Sitka spruce (Picea sitchensis) and Douglas fir (Pseudotsuga menziesii) zones of the Oregon Coast Range (Franklin and Dyrness 1973), which included the Clatsop, Tillamook, and Elliott State Forests.

Fire, wind throw, historic logging, and modern forest management helped create current structure and characteristics of the forests in Oregon. Our study area in the Oregon Coast Range was characterized by rugged, mountainous terrain, with steep slopes and deeply cut river and creek drainages. The landscape consisted of a mosaic of young, mature, and old-growth coniferous forests. Sampled stands in Oregon ranged in age from 65 to 167 years (although nest trees were 66 to 550 years in age $[x=170, S D=98]$ ), and were located outside recent (1900s) burn or windthrow areas. Stands ranged from 109 to $536 \mathrm{~m}$ in elevation, 13 to 125 ha in size, and were located 5.8 to $29.3 \mathrm{~km}$ inland. These sites were characterized by presence of older and larger trees and variation in tree age, which resulted in heterogeneous and multilayered canopies. Murrelet use of younger stands ( $<100$ years) is often predicated on presence of remnant older trees containing necessary nest platform structures. However, western hemlock trees in the Sitka spruce zone were often infected with dwarf mistletoe (Arceuthobium tsugense subsp. tsugense) providing more opportunities for nesting in smaller diameter trees. Trees $<100$ years in age would typically not have suitable platforms without the presence of a defect like mistletoe, which creates broom-like branch whorls or makes individual limbs larger in size. Of the 
stands sampled, $26 \%$ ( 9 of 34 ) were $<100$ years old and all the nest trees that were $<100$ years old in these younger stands had dwarf mistletoe.

The structure and characteristics of the forests sampled in Washington's Olympic Peninsula were heavily influenced by fire and windthrow along with past high-grade logging and modern forest management. Stands ranged in age from 125 to greater than 250 years old. Most sampled stands were in the lowlands of the Western Olympic Peninsula and were characterized by topography of moderate relief and gentle sloping terrain (Franklin and Dyrness 1973). Stands ranged from 75 to $803 \mathrm{~m}$ in elevation, 25 to 103 ha in size, and were $3.2 \mathrm{~km}$ to $31 \mathrm{~km}$ from the Pacific Coast. The lowland forests of the western Olympic Peninsula have been heavily modified by forest management beginning in the late 1870 s, resulting in a mosaic of young, mature, and old growth. Ten hurricane-force wind events have affected forest structure on the western Olympic Coast over the past 200 years (Henderson et al. 1989). Past fires have also affected this landscape, but less so than windthrow. Most stands sampled were in the Western Hemlock zone and $100 \%$ of stands sampled had dwarf mistletoe present.

\section{Sampling design}

We randomly selected study sites from a sample of known murrelet occupied stands in each study area. We selected six stands on the western and northern Olympic Peninsula in Washington between 1996 and 1998, and 34 stands in the northern and southern Coast Range in Oregon between 1995 and 1999. We used a stratified sampling design and intensive tree climbing to locate active and old murrelet nests trees during the breeding season (May-Oct). To select areas to climb within each stand, we overlaid a grid (6400 $\mathrm{m}^{2}$ quadrats) on an aerial photo of an occupied stand (contiguous forest with similar tree age distribution) and randomly selected $2-12$ grids to be sampled. Each grid number selected was visited on the ground to assess abundance of platforms. Potential nest platforms were defined as limbs or deformities that were $\geq 10 \mathrm{~cm}$ in diameter and $\geq 10 \mathrm{~m}$ in height (Evans Mack et al. 2003). If no platforms were available in the grid, then another grid number was randomly selected. Number of grids selected per site varied with size of the sampling area, logistics, and economics. On each grid selected, we established a 0.2 ha ( $25 \mathrm{~m}$ radius) circular tree climbing plot if at least one potential nest platform was present. The 0.2 ha climbing plot represented the scale of a patch for all analyses.

Within each climbing plot, all trees with at least one potential platform (observable from the ground) were accessed via ropes and ascenders (Perry 1978) to locate active or old nests. Trees with branches that were difficult to see from the ground or those that had inadequate limb structure were viewed from adjacent trees by climbers to see if they had potential platforms. Climbers carefully searched each tree limb for presence of a murrelet nest. They identified recently active nests by presence of fecal rings, eggshell fragments, or feathers, and old nests by presence of a nest cup, landing pad(s), or old eggshell fragments. We trained eight tree climbers in Oregon and three tree climbers in Washington in the nest search protocol, including minimizing disturbance to the canopy community while climbing trees. Tree climbing occurred from May to August in Oregon and from May to October in Washington.

\section{Habitat characteristics}

We measured habitat characteristics at three fine spatial scales at each sampling location: platform, tree, and forest patch. Forest patch was measured using a 0.2 ha circular vegetation plot that was centered on the tree closest to grid center. Therefore, the words "plot" and "patch" are used interchangeably in this paper. If nests were located in a climbing plot, a different 0.2 ha vegetation sampling plot was centered on each nest tree to characterize the nest site. If no nests were observed in a climbing plot, patch scale habitat characteristics were derived from the original 0.2 ha vegetation plot, centered at the same location as the climbing plot. For all trees with one or more platforms in each plot, we collected the following data from the ground: tree number, tree species, tree diameter $(\mathrm{dbh} ; \mathrm{cm})$, and number of platforms. On five randomly selected platforms and any nest platforms in each tree (number was fewer if tree had $<5$ platforms), we recorded platform height (m), platform diameter $(\mathrm{cm})$, percent moss cover, moss depth (five categories: $0=$ none, $1=$ trace, $2=1-2 \mathrm{~cm}, 3=3-4 \mathrm{~cm}, 4=>4 \mathrm{~cm}$, $5=$ not discernable), and percent horizontal cover (to the sides of the branch) in four categories ( $0=$ none, $1=1-33 \%, 2=34-66 \%$, $3=67-100 \%$ ). In addition, climbers counted number of platforms on each tree; and, on three platforms in each tree, measured moss depth $(\mathrm{cm})$.

To characterize each forest patch, we measured canopy closure $(\%)$ and also calculated the variation in tree size by using the standard deviation of tree diameter for all trees $>10 \mathrm{~cm} \mathrm{dbh}$. We also used platform counts collected by climbers to calculate number of platforms/ha.

\section{Analyses}

We selected a priori variables at each scale, based on a careful review of murrelet literature, rather than completing an exploratory search through potential covariates. At the platform scale (ground observed data), we included measurements of platform diameter (DIAM), percent moss cover (MOSS), and percent horizontal cover (HORCOV). At the tree scale (climber assessed data), we included tree diameter (DBH), a climber count of number of platforms $>10 \mathrm{~cm}$ in diameter (PLATCL), and a measurement of average moss depth on platforms (DEPTH). At the patch scale (ground and climber assessed data), we included the standard deviation of tree diameter (for all trees $>10 \mathrm{~cm} \mathrm{dbh}$ ) or variation in tree size (SDDBH10), percent canopy cover (CANOPY) and number of platforms/ha (CLPLATHA). We did not have a sufficient sample of nests to develop models on subsets of these data, e.g., patches with dwarf mistletoe platforms versus non-dwarf mistletoe patches, stand age, forest type, etc.

We used a generalized linear mixed model (GLMM) to account for the four sampling scales (stand, patch, tree, platform), and to account for the case-control sampling design used at the tree and platform levels (Breslow and Clayton 1993). We let $y_{i j k l}$ denote nest status of platform $l$ from tree $k$ in patch $j$ and stand $i$, where $y_{i j k l}=1$ if there is evidence of a murrelet nest on the platform, and $y_{i j k l}=0$ otherwise. The nest status is assumed to arise from a conditional Bernoulli distribution: $y_{i j k l} \mid x_{i j k l} \sim \operatorname{Bern}\left(\psi\left(x_{i j k l}\right)\right)$, where $\psi\left(x_{i j k l}\right)$ is the probability of a murrelet nest on the platform, conditional on the vector of covariates $x_{i j k l}$. Specifically, we assumed that: 


$$
\begin{gathered}
\log \left(\psi_{i j k l}\right)=\beta_{0}+b_{0, i}+b_{0, i j}+b_{0, i j l}+\beta_{1} \operatorname{SDDBH} 10_{i j}+ \\
\beta_{2} \text { CANOPY }_{i j}+\beta_{3} \text { CLPLATHA }_{i j}+\beta_{4} B D H_{i j k}{ }^{+} \\
\beta_{5} \text { DEPTH }_{i j k}+\beta_{6} \text { PLATCL }_{i j k}+\beta_{7} \text { DIAM }_{i j k l}+ \\
\beta_{8} \text { HORCOV }_{i j k l}+\beta_{9} \text { MOSS }_{i j k l}
\end{gathered}
$$

where model random effects $\left(b_{0, i^{*}}\right)$ are assumed to arise from mutually independent normal distributions with mean zero and separate variances. We used a log-link function to allow for simpler interpretation of the model coefficients, and note that for small expected probabilities, results will be similar for either log or logit link functions. Random effects $b_{0, i}, b_{0, i j}$, and $b_{0, i j k}$ were included to account for correlation among measurements taken in the same stand, patch, or tree. Our discretized measures of percent horizontal cover (HORCOV) and average moss depth $(\mathrm{DEPTH})$ were treated as continuous variables. All covariates were centered and scaled prior to analysis.

We fit our model in a Bayesian framework to aid estimator stability through the regularizing effect of the prior distributions (Hoerl and Kennard 1970). Only observations with complete data records necessary for fitting the model were included in the analysis. We did not impute any missing data. We used $N(\mu=0$, $\left.\sigma^{2}=10\right)$ priors for all model coefficients except for the intercept, and a $N\left(\mu=-6, \sigma^{2}=2\right)$ for the model intercept. The intercept prior was chosen based on a preliminary fit using maximum likelihood and reflects the low nest-platform density among patches in our study. We further note that the intercept in a casecontrol study design cannot be interpreted directly without additional information (Keogh and Cox 2014). Patch and site random effect standard deviations used $\operatorname{Unif}(0.01,2)$ prior distributions, while the tree random effect standard deviation used $\operatorname{Unif}(0.1,3)$. We fit the model using JAGS (Plummer 2003) called from R (R Development Core Team 2019) using package R2jags (Su and Yajima 2015). We ran four chains of length 55000 with 5000 burn-in and 1/100 thinning. Convergence was assessed using the Gelman-Rubin statistic (Gelman et al. 2004) and visual inspection of the chains, with results consistent with Markov chain convergence. We used posterior predictive checks to assess agreement between the fitted model and the observed data.

\section{Results}

In Washington, we found 20 nest trees and 27 nest platforms (because of multiple nest platforms in some trees). In Oregon, we found 19 nest trees and nest platforms. Thirty-two (82\%) nest trees were found in the western hemlock zone of the Olympic Peninsula and northwest Coast of Oregon and seven (18\%) nest trees were in the Douglas fir zone in the central coast of Oregon. For both states combined, murrelet nests were found in 46 of $6144(0.75 \%)$ platforms sampled, 39 of $1502(2.6 \%)$ trees sampled, and 34 of $187(18.2 \%)$ patches sampled. In the Oregon portion of the study, no trees had more than one nest, two patches had multiple nest trees ( $\mathrm{n}=2$ and 3 nest trees/patch), and four stands had multiple nests $(\mathrm{n}=3-6)$. In Washington, four trees had multiple nests ( $\mathrm{n}$ $=2-4)$, five patches had multiple nest trees $(n=2-4)$, and four stands had multiple nests $(\mathrm{n}=3-10)$. Average density of nests combined was 0.94 nests/ha. Only one active nest was found in the central coast of Oregon; no active nests were found in Washington.

In Oregon, 24 nest trees were re-climbed up to three years after they were active (Nelson and Peck 1995; Nelson, unpublished data) and these nests were found to persist for at least three years. From 1998 to 2000, researchers also re-climbed eight nests in Oregon originally found in 1990-1992 and nests and landing pads were still evident after 8-10 years (Nelson, unpublished data).

All the western hemlock nest trees $(n=12)$ in Oregon were infected with dwarf mistletoe except two, which were isolated western hemlock nest trees within the drier Douglas fir zone where this mistletoe generally does not occur. Nine nest trees had no dwarf mistletoe including one Sitka spruce tree, six Douglas fir, and two western hemlock trees. In Washington, all the western hemlock nest trees $(n=17)$, except one, were infected with dwarf mistletoe. This was true even for nests found in older western hemlock trees. Four nest trees had no dwarf mistletoe, and of these, two were located in Sitka spruce and one each in a Douglas fir and western hemlock. Although tree species may covary with forest characteristics important for murrelet nest site selection, we did not explicitly account for tree species in our hierarchical model.

Results of the fitted model highlighted forest characteristics at each of the three scales that differentiated locations with a nest from randomly selected locations that did not have nests (Table 1). At the platform scale, platform diameter, percent moss cover, and percent horizontal cover were positively associated with $\mathrm{Pr}$ (nest) (Fig. 1 and Table 2). Holding all other covariate values in the model constant at mean values, a $1 \mathrm{SD}$ difference in percent moss cover (SD: 28\%) was associated with an estimated 1.5 times higher $\operatorname{Pr}($ nest) (Table 2 and Fig. 1). For the index of percent horizontal cover (SD: 0.9 ) and platform diameter (SD: $7 \mathrm{~cm}$ ) we estimated a 2.6 times and 1.9 times difference, respectively, in the $\operatorname{Pr}$ (nest) for each 1 SD difference in the covariate, holding all other variables constant (Table 2 and Fig. 1).

At the tree scale, number of platforms on the tree, and average moss depth were positively associated with $\operatorname{Pr}($ nest), after adjusting for other model covariates. There was an estimated 1.9 times higher $\operatorname{Pr}($ nest) in trees with 1 SD higher (SD: 15 platforms) counts of total platforms $>10 \mathrm{~cm} \mathrm{DBH} \mathrm{(Table} 2$ and Fig. 1). We estimated a 1.6 times difference in nest probability for each $1 \mathrm{SD}$ $(2 \mathrm{~cm})$ difference in average moss depth (Table 2 and Fig. 1). Results were ambiguous for the association between tree diameter (DBH) and $\operatorname{Pr}$ (nest), where uncertainty in the estimates did not preclude positive associations, negative associations, or values close to zero.

At the patch scale, we found platform density per hectare to be negatively associated with $\operatorname{Pr}$ (nest), after adjusting for trends with other model covariates. There was an estimated 60\% lower Pr (nest) in patches with $1 \mathrm{SD}$ higher (SD: 620 platforms/ha) platform density (Table 2 and Fig. 1). The direction of effect on $\operatorname{Pr}$ (nest) was unclear for patch scale canopy cover and variation in tree size.

\section{DISCUSSION}

Despite only sampling stands with known occupancy, it was rare to encounter evidence of a murrelet nest in an individual patch, tree, or platform. One nest was found for every 134 platforms, 39 platform trees, or 5.5 forest patches sampled, resulting in an average nest density of 0.94 per ha. By comparison, in the relatively contiguously forested areas of the Ursus Valley and Clayoquot Sound, on the west coast of Vancouver Island, British Columbia, intensive tree-climbing searches in occupied stands resulted in nest density estimates of 0.60 and 0.53 nests per ha, respectively (Conroy et al. 2002, Burger and Waterhouse 2009). 
Table 1. Mean, standard deviation, minimum and maximum values for each variable included in the generalized linear mixed model for nest and non-nest categories. Values are shown for the three scales analyzed: nest and non-nest patches, trees, and platforms. The sample sizes for each variable are shown in parenthesis. Cases with missing data were removed from the analysis.

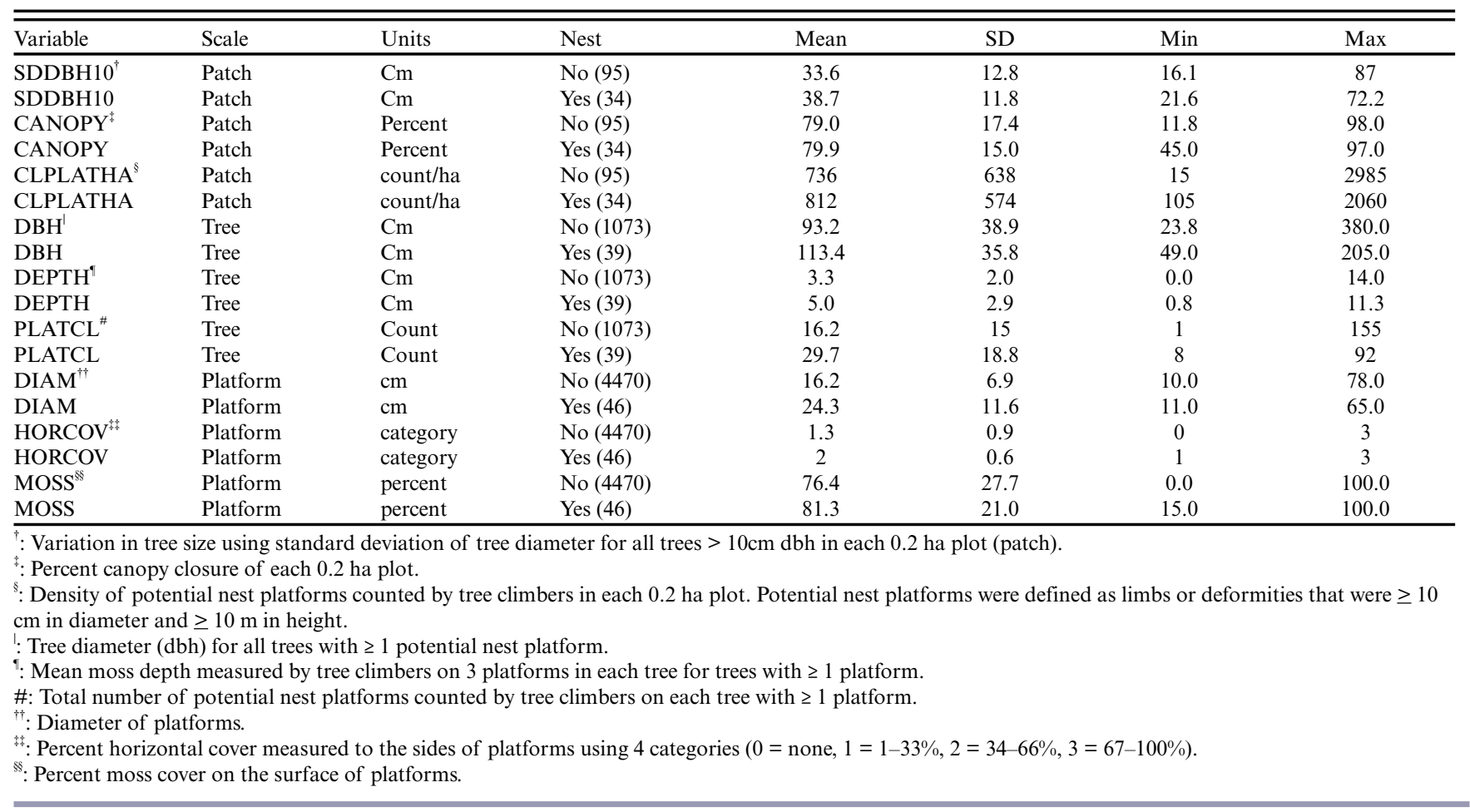

In comparatively more fragmented forests on the Sunshine Coast, British Columbia, nest densities ranged from 0.30 to 0.70 nests per ha (Manley 1999; no distinction made between old and active nests). In terms of active nest density, there are limited data. Conroy et al. (2002) estimated a density of 0.13 active nests per ha, but that estimate was based on only one active nest. Therefore, our average nest density was to 1.3 to 7 times higher than other studies. More data on nest densities from different regions will be needed to help understand these differences.

In contrast with exploratory approaches, the nine terms included in our model were chosen to represent factors from multiple scales with prior support in the literature for influencing murrelet nest selection. Our objective was to independently assess these associations with data from an extensive survey of stands with a history of murrelet occupancy. Unlike other studies of murrelet nest selection, the hierarchical logistic regression approach we chose provides an analysis of murrelet nest selection at three scales simultaneously, thereby addressing partial confounding among covariates at different scales. However, our results do not provide assessments of the relative importance of each scale on murrelet nest selection. A different choice of covariates could lead to different conclusions regarding importance of each scale. Compared to prior efforts, our analysis benefits from a large sample size and using a hierarchical model to account for sampling across multiple scales.

\section{Platform scale}

Forest characteristics around platforms may affect nest-site selection through their influence on the micro-climate of a nest site including levels of solar radiation, relative humidity, and temperature (van Rooyen et al. 2011). Estimated Pr(nest) was positively related to amount of moss cover on the nest platform, amount of horizontal cover around the nest platform, and diameter of the platform itself.

Murrelets may select nest sites to minimize risk of predation by using platforms in trees with large, dense crowns for vertical and horizontal protection (cover; Hamer and Nelson 1995). Nest site selection driven by predation avoidance would reflect importance of platform scale factors, including nest position related to the tree canopy and bole and concealment or shielding. Other potential factors influencing platform-scale nest-site selection may include ease or difficulty of adults entering and leaving the nest and for a chick to fledge successfully on its first flight to the ocean.

High moss cover creates nest platform choices by providing nesting substrate on many locations on a single limb, especially where overhead cover and limb diameter are sufficient (Hamer 1995). Because murrelets do not build a nest and merely make a nest scrape (Hamer and Nelson 1995), moss also acts as a nest substrate. Nestlings are known to fall from nests (Binford et al. 1975, Nelson and Hamer 1995b, Manley 1999), and it is assumed that greater moss cover would facilitate formation of nest cups and help prevent accidental rolling of an egg or a nestling off the nest platform (Manley 1999). Moss also may provide additional insulation to eggs and chicks (Naslund et al. 1995).

In coastal British Columbia, Burger et al. (2010) found that most trees providing platforms had moss covering one-third or more 
Table 2. GLMM mean covariate coefficients and 90\% posterior credible intervals. Estimates are interpreted as the multiplicative difference in nest probability associated with a 1-unit difference in the covariate. Estimates greater than 1.0 indicate a positive association, while estimates less than 1.0 indicate a negative association.

\begin{tabular}{|c|c|c|c|c|c|}
\hline Covariate & Scale & $\mathrm{SD}$ & $\exp$ (coef) & $\exp (5 \%$ LL $)$ & $\exp (95 \% \mathrm{UL})$ \\
\hline$\overline{\mathrm{SDDBH} 10^{\dagger}}$ & patch & 13 & 1.5 & 0.8 & 2.6 \\
\hline $\mathrm{CANOPY}^{*}$ & patch & 17 & 1.0 & 0.6 & 1.8 \\
\hline CLPLATHA $^{\S}$ & patch & 620 & 0.4 & 0.2 & 0.7 \\
\hline $\mathrm{DBH}^{\prime}$ & tree & 39 & 0.8 & 0.5 & 1.3 \\
\hline DEPTH $^{\llbracket}$ & tree & 2.0 & 1.6 & 1.2 & 2.3 \\
\hline PLATCL ${ }^{\#}$ & tree & 15 & 1.9 & 1.3 & 2.8 \\
\hline DIAM $^{\dagger \dagger}$ & platform & 7.0 & 1.9 & 1.5 & 2.4 \\
\hline $\mathrm{HORCOV}^{*}$ & platform & 0.86 & 2.6 & 1.9 & 3.7 \\
\hline $\operatorname{MOSS}^{\S \S}$ & platform & 28 & 1.5 & 1.1 & 2.3 \\
\hline
\end{tabular}

: Variation in tree size using standard deviation of tree diameter for all trees $>10 \mathrm{~cm}$ dbh in each 0.2 ha plot (patch)

: Percent canopy closure of each 0.2 ha plot.

$\S$ : Density of potential nest platforms counted by tree climbers in each 0.2 ha plot. Potential nest platforms were defined as limbs or

deformities that were $\geq 10 \mathrm{~cm}$ in diameter and $\geq 10 \mathrm{~m}$ in height.

: Tree diameter $(\mathrm{dbh})$ for all trees with $\geq 1$ potential nest platform.

: Mean moss depth measured by tree climbers on 3 platforms in each tree for trees with $\geq 1$ platform.

\#: Total number of potential nest platforms counted by tree climbers on each tree with $\geq 1$ platform.

it: Diameter of platforms.

: Percent horizontal cover measured to the sides of platforms using 4 categories $(0=$ none, $1=1-33 \%, 2=34-66 \%, 3=67-100 \%)$.

s: Percent moss cover on the surface of platforms.

Fig. 1. Estimates of relative difference in the $\operatorname{Pr}($ nest) for a $1 \mathrm{SD}$ difference in each model covariate, holding all other covariates fixed constant. Thin error bars show $90 \%$ posterior credible intervals. Thick error bars show $50 \%$ posterior credible intervals. An estimate of 1.0 indicates no relative difference in nest probability associated with the covariate. MOSS: Percent moss cover on the surface of platforms; HORCOV: Percent horizontal cover measured to the sides of platforms using 4 categories $(0=$ none, $1=1-33 \%, 2=34-66 \%, 3=67-100 \%)$; DIAM: Diameter of platforms; PLATCL: Total number of potential nest platforms counted by tree climbers on each tree with $\geq 1$ platform; DEPTH: Mean moss depth measured by tree climbers on 3 platforms in each tree for trees with $\geq 1$ platform; DBH: Tree diameter (dbh) for all trees with $\geq 1$ potential nest platform; CLPLATHA: Density of potential nest platforms counted by tree climbers in each 0.2 ha plot. Potential nest platforms were defined as limbs or deformities that were $>10$ $\mathrm{cm}$ in diameter and $>10 \mathrm{~m}$ in height; CANOPY: Percent canopy closure of each 0.2 ha plot; SDDBH10: Variation in tree size using standard deviation of tree diameter for all trees $>10 \mathrm{~cm}$ dbh in each 0.2 ha plot (patch).

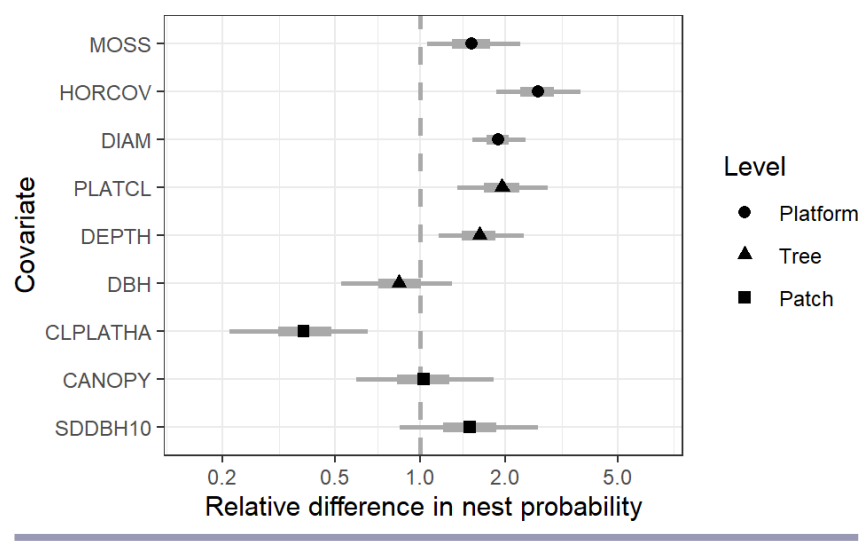

of their branches. Silvergieter and Lank (2011b) compared nest trees to unused trees in $25 \mathrm{~m}$ plots and found that murrelet nest trees did not have significantly more moss cover than other platform trees in the plot. However, Manley (1999) compared nest limbs to other limbs available in nest trees and found most nests were on platforms with a thick moss layer; platforms bare of moss were not used and platforms with thin moss cover were avoided. In a study comparing known nest sites with sites at randomly located points in greater than 140-year-old forests in south coastal British Columbia, moss development (along with slope grade and elevation) proved one of the best predictors of murrelet nest patches (Waterhouse et al. 2009).

Horizontal cover around a platform had the highest relative difference in probability between nest platforms and non-nest platforms (Fig. 1 and Table 2). No other study to date has analyzed this particular nest site characteristic, so there is little information on importance of this variable in murrelet nest-site selection. One study (Manley 1999) on the Sunshine Coast of B.C. compared overhead cover (as opposed to horizontal cover measured in our study) in three categories above nest platforms to amount of cover above other platforms available in the same nest tree. She found covered platforms were preferred for nesting. Because predation is known to be a significant factor at nest sites (Nelson and Hamer 1995b, Manley 1999, Bradley 2002, Nelson and Wilson 2002, McShane et al. 2004), and many known nest predators, e.g., corvids, are birds that detect prey visually (Nelson and Hamer 1995b, Manley 1999, Nelson 2020), amount of horizontal cover around the nest is likely an important nest site characteristic. In a study of nest success, Hamer and Nelson (1995) found that successful nests were significantly further from stand edges and were better concealed ( $x=87$ versus $67 \%$ cover) than unsuccessful nests.

Larger diameter platforms may provide multiple benefits to nesting murrelets including providing larger areas for adults to land and take off from the platform without endangering the egg or young. 
Hamer and Nelson (1995) reported observing and hearing murrelets crashing into tree limbs during final approaches to nests. Manley (1999) found that nest limbs were significantly larger in diameter and had a greater platform area than other limbs available in nest trees. Larger platforms also provide more space for the young to develop and for both adults to perch on a limb simultaneously as both adults sometimes arrive with fish for the fledgling within minutes of each other (Nelson and Hamer 1995a, Jones 2001). In addition, larger platforms may add to visual screening from potential predators. Because there have been no other papers that have compared size of platforms between nest and non-nest patches, trees and non-nest trees, or nest platforms and non-nest platforms, we recommend this comparison in future studies.

In coastal forests of western Oregon and Washington, dwarf mistletoe occurs in western hemlock trees in the Sitka sprucewestern hemlock zone. Dwarf mistletoe also occurs in Douglas fir trees in the Douglas-fir zone, but primarily on the east side of the coastal mountain ranges (Hawksworth and Wiens 1996). In our study sites, $25 \%$ of nests were found in forests less than 100 years in age and $24 \%$ of nests were located on mistletoe-infected limbs. Despite not occurring consistently throughout our study sites, the enlarged limbs and brooms created by this parasite can provide appropriate conditions for nesting murrelets in younger forests.

\section{Tree scale}

Our fitted model found $\operatorname{Pr}($ nest) to be positively related to total number of platforms ( $>10 \mathrm{~cm}$ diameter $)$ in a tree, after controlling for other model factors. Manley (1999) also concluded that there was strong selection for trees with more platforms over other available trees. However, in a comparison of nest and non-nest trees in Clayoquot Sound, British Columbia, Conroy et al. (2002) failed to find more platforms in nest trees vs. non-nest trees. In addition, Silvergieter and Lank (2011b) concluded that murrelets chose platforms without respect to number of platforms per tree. However, nest trees in our study often had more platforms than other trees in the plot, containing, on average, five more platforms than other available, but unused, platform trees. Murrelets may select trees with more than one platform so they can alternate between platforms in the same tree in successive years to avoid predation, although reuse of the same nest platform is rare (Singer et al. 1995, Nelson and Wilson 2002, Hébert et al. 2003, Burger et al. 2009). Alternating nest locations in successive years among platform trees in a patch or stand is more common and may give murrelets an advantage in escaping detection from predators (Burger et al. 2009). However, only a few nest trees have been followed for more than one to three years, so documentation of nest reuse needs further study.

$\operatorname{Pr}$ (nest) was positively associated with mean depth of moss on the tree. Greater moss depth increases platform diameter which can transform limbs of marginal size into larger usable platforms; larger platforms were shown to have higher probabilities of nest use at the platform scale in this study. Similar to moss cover at the platform scale, presence of thicker moss pads or epiphyte mats also may increase nesting opportunities. Murrelet nesting was correlated with increased moss depth in several studies (Conroy et al. 2002, Burger and Bahn 2004, Silvergeiter and Lank 2011b).
We note that in our sample of trees and platforms, there was negligible correlation between platform moss cover and treeaverage moss depth $(\rho=0.07)$, suggesting that these may act as independent factors affecting murrelet nest selection. Further south in coast redwood (Sequoia sempervirens) forests, moss is much less available, and murrelets often use platforms covered in needles and duff (Hamer and Nelson 1995). Therefore, our results on moss cover and depth are relevant for Oregon and Washington and areas further north.

Platform size, amount of moss cover and moss depth at the nest, percent of overhead and horizontal cover around a nest, degree of access when entering or leaving a nest, presence of adjacent suitable landing pads, and exposure of a nest to solar radiation, wind, and precipitation would likely be determined by choice of a particular platform, not a particular tree or forest patch. Moss depth at the tree scale and moss cover at the platform scale were indicative of favorable micro-climate characteristics for the growth of these epiphytes. Mosses and other epiphytes growing on the limbs of trees cannot control water uptake or retention, are completely dependent on air moisture and precipitation as water sources, and thus are strongly influenced by forest edge proximity and changing climate (Busby et al. 1978, van Rooyen et al. 2011). These same factors may influence murrelets directly through heat stress of adults and chicks at nest sites (McShane et al. 2004, Meyer et al. 2004). Trees with higher numbers of platforms may also have a higher probability of containing one platform that provides the necessary micro-climate and cover, yet that relationship does not appear consistent at the patch scale.

There was no clear association between tree diameter and $\mathrm{Pr}$ (nest), after adjusting for other model covariates. Outside of Oregon and Washington, only four studies have compared nest tree diameter to surrounding trees. These California and British Columbia studies found murrelet nest trees were larger in diameter than other trees in the surrounding forest patch (Manley 1999, Baker et al. 2006, Golightly et al. 2009, Silvergieter and Lank 2011b).

In this study, $69 \%$ of nest sites were in the western hemlock zone and $67 \%$ of our nest trees were infected with dwarf mistletoe, although not necessarily at the nest platform. When dwarf mistletoe is present in the canopy, the relationship of tree diameter to likelihood of nesting becomes less clear, because many younger western hemlock trees with dwarf mistletoe have suitable sized platforms at younger ages and thus smaller tree diameters (Hamer 1995, Nelson and Wilson 2002). Future studies should determine if nests are on dwarf mistletoe-infected limbs versus other platform types.

Unusual limb deformations, decadence, and tree damage, commonly observed in older aged, heterogeneous stands, can also create usable nest platforms (Hamer and Nelson 1995). Similarly, moss or larger accumulations of duff, multiple overlapping tree limbs, natural limb deformities, and disease can create nesting opportunities. Hamer (1995) concluded that stand structure was more important in predicting stand occupancy by murrelets than the size of the trees within the stand. However, Burger et al. (2010) found that tree diameter was the best predictor of platform availability in six regions of British Columbia. Raphael et al. (2011) found a correlation between tree size and number of 
platforms, and platforms (a variable created with tree per hectare and tree diameter) was the most important predictor of murrelet nesting habitat. Manley (1999) also found that numbers of platforms were highly correlated with tree diameter. Tree size can be a predictor of platform presence on some species, but tree size alone is likely not the most important variable in murrelet nest habitat selection in Oregon and Washington. Platform size, at least to a minimum threshold, may be more critical because murrelets do not build a nest and thus rely on a large platform to accommodate the chick and provide landing pads for adults. Tree size $(\mathrm{DBH})$ and platform size (DIAM) were weakly correlated ( $\rho$ $=0.30$ ) in our study. A particular benefit of the hierarchical modeling approach used for this analysis is the ability to account for partial confounding among covariates at different scales when estimating model parameters (Gelman 2006).

\section{Patch scale}

Stand structure and patch scale attributes may be more important than tree diameter alone in producing nesting platforms (Hamer 1995), especially when considering the number of nests found in younger western hemlock stand in this study and the high proportion of nests found on dwarf mistletoe-infected branches. $\operatorname{Pr}$ (nest) was negatively associated with number of platforms counted in the patch. Thus, a randomly selected platform from a forest patch with high platform density will have a lower $\operatorname{Pr}($ nest) than a randomly selected platform from a patch with a low platform density. This finding may support Silvergieter and Lank (2011b) who concluded that murrelets chose particular platforms without respect to number of platforms per tree. However, Manley (1999) found that murrelets exhibited selectivity at the patch scale for density of trees and number of nesting platforms.

Murrelets are social like other Alcids and commonly interact and vocalize to each other over nesting stands where multiple pairs are known to nest (Manley 1999, Nelson and Wilson 2002). Prerecorded broadcasts of murrelet calls in suitable habitat have been shown to increase the likelihood of occupancy of these stands indicating social information influences the selection of breeding sites (Valente et al. 2021). However, murrelets are known to disperse their nest sites throughout forest stands (Naslund et al. 1993, Bradley et al. 2002). Murrelets often alternate use of platforms within their nest stands among years to avoid predation (Singer et al. 1995, Nelson and Wilson 2002, Burger et al. 2009). The number of platforms or platform trees required for each pair is unknown and nest spacing may obscure potential relationships between $\operatorname{Pr}($ nest) and platform density. Platform density and platform diameter were weakly positively correlated in our dataset. A post-hoc analysis provided no evidence of an interaction effect between platform size and density, suggesting that the estimated negative association between $\operatorname{Pr}($ nest) and platform density was not due to partial confounding with platform diameter.

If local murrelet populations are currently maintained or limited by some combination of loss of old growth forest, predation, and off-shore foraging resources (Peery et al. 2004, Norris et al. 2007, Betts et al. 2020), the inland-breeding population may not fully use available nesting sites. One might expect greater use of existing nesting sites (more platforms in close proximity receiving use) if regional populations were to increase.
A portion of the explanation for the unexpected negative relationship between platform density and $\operatorname{Pr}$ (nest) may lie in simple probability. The likelihood of observing a nest on a single platform declines when there are more platforms in a patch. For example, in two patches containing one nest each, the patch with more platforms will have a lower probability of any one platform containing a nest. The same logic would apply to number of platforms in a tree. In the absence of any other effect, we would expect an inverse relationship between the $\operatorname{Pr}($ nest) and any density measure. However, in contrast to platform density at the patch scale, the relationship between tree scale platform counts and $\operatorname{Pr}$ (nest) was positive. Obviously, murrelets need platforms and at some scale the number available becomes important.

Effects of average canopy closure and tree diameter standard deviation (a measure of canopy complexity) on $\operatorname{Pr}($ nest) were unclear, with plausible estimates for the effect being positive, negative, or close to zero. Some researchers have found canopy closure to be negatively related to likelihood of nesting (Waterhouse et al. 2002) and negatively related to stand occupancy (Hamer 1995), recognizing that the sphere of potential inference for that negative relationship is closed canopy, mature forest stands. At the patch level, Manley (1999) found no evidence of selection for the size or types of gaps in a patch. Other researchers have found measures of vertical complexity to be positively related to likelihood of nesting (Conroy et al. 2002, Waterhouse et al. 2002, Silvergieter and Lank 2011a), numbers of occupied behaviors observed (Bahn and Newsom 2002, Burger and Bahn 2004), and likelihood of occupancy (Hamer et al. 2008).

\section{Summary}

The hierarchical model structure employed in this analysis allowed assessment of habitat characteristics while adjusting for partial confounding across multiple scales. However, it did not provide for comparisons of the strength of habitat selection among the platform, tree, and patch scales. Considering the relative differences in $\operatorname{Pr}($ nest) associated with each of the nine covariates, model results indicated that several forest characteristics at the branch/platform and tree scales are important in nest-site selection by murrelets. However, we did not assess the conditions, e.g., cover, at platforms and the local environment surrounding $(<3 \mathrm{~m})$ platforms that will affect adult and chick survival throughout the nesting period, including nest success.

Habitat recruitment has been identified as an important recovery strategy in the USFWS Marbled Murrelet Recovery Plan (USFWS 1997). To facilitate that objective, it will be beneficial to consider silvicultural methods promoting development of (1) large branches with high percentages of moss cover and deep moss pads; (2) a high proportion of horizontal cover around platforms (dense crowns); (3) trees with larger numbers of platforms and; (4) dwarf mistletoe presence in younger stands that could promote platform development. Future research efforts could focus on model development to rank the relative suitability of individual trees within stands, which would help identify those trees that contribute most to nesting habitat.

This study pioneered intensive tree climbing as a viable method for locating nest sites of murrelets in known occupied stands. The only feasible approach for such an intensive climbing effort was 
to focus on previously identified occupied sites with evidence of past nesting. Although somewhat daunting in scope, future research should focus on the association between forest characteristics and murrelet nest success and determining the scale of greatest influence for nest-site selection.

Responses to this article can be read online at: https://www.ace-eco.org/issues/responses.php/1883

\section{Acknowledgments:}

We are grateful for the field assistance of $K$. Augenfeld, S. Bahe, A. Bate, L. Battels, M. Briton, D. Buchholz, D. Burger, K. Charleton, J. Coury, K. Cradler, D. Crannell, T. DeSanto, R. Espanosa, B. Fields, L. Fish, S. Freeman, R. Gerig, D. Gilbert, G. Gillson, J. Grenier, J. Guetterman, J. Hardin, R. Harper, P. Harrison, E. Harrison-Kuo, S. Hoefs, S. Hogan, S. Hopkins, S. Horton, B. Howell, R. Hubbard, D. Huber, S. Hughes, K. Jordan, I. Kellogg, D. Kershaw, N. Kitchanantha, C. Knauf, K. Kritz, N. Krocker, G. Lacata, S. Livingston, W. Logan, S. Lundsten, D. Mc Carthy, J. Megahan, M. Monserrat, L. Moore, M. Nugent, C. Osborne, R. Peck, M. Pope, R. Rainbolt, J. Reams, J. Rogers, M. Shaughnessy, J. Wells, S. Williamson, M. Wilson, W. Wright, and many others. We also thank our tree climbers for their efforts: $D$. Attwell, W. DeMoray, B. Ellyson, P. Engelmeyer, E. Forsman, S. Foster, K. Hanneman, K. Hillary, J. Hinkle, S. Hughes, J. Howe, S. Hyde, K. Jordan, D. Laughlin, B. Lovelace, M. Nixon, M. Oxman, S. Sillett, J. Spickler, S. Stephens, G. Summers, J. Thompson, J. Tremblay, and D. Wallower. B. Ritchie shared data on murrelet nests from the Washington Department of Fish and Wildlife database.

\section{LITERATURE CITED}

Bahn, V., and D. Newsom. 2002. Can Marbled Murrelet use of nesting habitat be predicted from mapped forest characteristics? Pages 89-100 in A. E. Burger and T. A. Chatwin, editors. Multiscale studies of populations, distribution and habitat associations of Marbled Murrelets in Clayoquot Sound, British Columbia. Ministry of Water, Land and Air Protection, Victoria, British Columbia, Canada.

Baker, L. M., M. Z. Peery, E. E. Burkett, S. W. Singer, D. L. Suddjian, and S. R. Beissinger. 2006. Nesting habitat characteristics of the Marbled Murrelet in central California redwood forests. Journal of Wildlife Management 70:939-946. https://doi.org/10.2193/0022-541X(2006)70[939:NHCOTM]2.0.CO;2

Betts, M. G., J. M. Northrup, J. A. Bailey Guerrero, L. J. Adrean, S. K. Nelson, J. L. Fisher, B. D. Gerber, M.-S. Garcia-Heras, Z. Yang, D. D. Roby, and J. W. Rivers. 2020. Squeezed by a habitat split: warm ocean conditions and old-forest loss interact to reduce long-term occupancy of a threatened seabird. Conservation Letters 13:e12745. https://doi.org/10.1111/conl.12745

Binford, L. C., B. G. Elliot, and S. W. Singer. 1975. Discovery of a nest and the downy young of the Marbled Murrelet. Wilson Bulletin 87:303-319.
Bradley, R. W. 2002. Breeding ecology of radio-marked Marbled Murrelets (Brachyramphus marmoratus) in Desolation Sound, British Columbia. Thesis. Department of Biological Sciences, Simon Fraser University, Burnaby, British Columbia, Canada.

Bradley, R. W., L. A. McFarlane Tranquilla, B. A. Vanderkist, and F. Cooke. 2002. Sex differences in nest visitation by chickrearing Marbled Murrelets. Condor 104:178-183. https://doi. org/10.1093/condor/104.1.178

Breslow, N. E., and D. G. Clayton. 1993. Approximate inference in generalized linear mixed models. Journal of the American Statistical Association 88:9-25. https://doi.org/10.1080/01621459.1993.10594284

Burger, A. E. 2002. Conservation assessment of Marbled Murrelets in British Columbia: a review of the biology, populations, habitat associations, and conservation. Technical Report Series No. 387, Canadian Wildlife Service, Pacific and Yukon Region, Delta, British Columbia, Canada.

Burger, A. E., and V. Bahn. 2004. Inland habitat associations of Marbled Murrelets on southwest Vancouver Island, British Columbia. Journal of Field Ornithology 75:53-66. https://doi. org/10.1648/0273-8570-75.1.53

Burger, A. E., I. A. Manley, M. Silvergieter, D. B. Lank, K. M. Jordan, T. D. Bloxton, and M. G. Raphael. 2009. Re-use of nest sites by Marbled Murrelets (Brachyramphus marmoratus) in British Columbia. Northwestern Naturalist 90:217-226. https:// doi.org/10.1898/NWN08-50.1

Burger, A. E., R. A. Ronconi, M. P. Silvergieter, C. Conroy, V. Bahn, I. A. Manley, A. Cober, and D. B. Lank. 2010. Factors affecting the availability of thick epiphyte mats and other potential nest platforms for Marbled Murrelets in British Columbia. Canadian Journal of Forest Research 40:727-746. https://doi.org/10.1139/X10-034

Burger, A. E., and F. L. Waterhouse. 2009. Relationships between habitat area, habitat quality, and populations of nesting Marbled Murrelets. BC Journal of Ecosystems and Management 10:101-112.

Busby, J. R., L. C. Bliss, and C. D. Hamilton. 1978. Microclimate control of growth rates and habitats of the boreal forest mosses Tomenthypnum nitens and Hylocomuim splendens. Ecological Monographs 48:95-110. https://doi.org/10.2307/2937294

Committee on the Status of Endangered Wildlife in Canada (COSEWIC). 2012. COSEWIC assessment and status report on the Marbled Murrelet Brachyramphus marmoratus in Canada. COSEWIC, Ottawa, Ontario, Canada.

Conroy, C. J., V. Bahn, M. S. Rodway, L. Ainsworth, and D. Newsom. 2002. Estimating nest densities for Marbled Murrelets in three habitat suitability categories in the Ursus Valley, Clayoquot Sound. Pages 121-138 A. E. Burger and T. A. Chatwin, editors. Multi-scale studies of populations, distribution and habitat associations of Marbled Murrelets in Clayoquot Sound, British Columbia. Ministry of Water, Land and Air Protection, Victoria, British Columbia, Canada.

Evans Mack, D., W. P. Ritchie, S. K. Nelson, E. Kuo-Harrison, P. Harrison, and T. E. Hamer. 2003. Methods for surveying 
Marbled Murrelets in forests: a revised protocol for land management and research. Technical Publication Number 2. Pacific Seabird Group, Corvallis, Oregon, USA. [online] URL: https://pacificseabirdgroup.org/wp-content/uploads/2016/06/ PSG_TechPub2_MAMU_ISP.pdf

Franklin, J. F., and C. T. Dyrness. 1973. Natural vegetation of Oregon and Washington. U.S. Forest Service General Technical Report PNW-8.

Gelman, A. 2006. Multilevel (hierarchical) modeling: what it can and cannot do. Technometrics 48:432-435. https://doi. org/10.1198/004017005000000661

Gelman, A., J. B. Carlin, H. S. Stern, and D. B. Rubin. 2004. Bayesian data analysis. Second edition. Chapman \& Hall/CRC, Boca Raton, Florida, USA.

Golightly, R. T., C. D. Hamilton, and P. N. Hebért. 2009. Characteristics of Marbled Murrelet (Brachyramphus marmoratus) habitat in Northern California. Final Report, Humboldt State University, Department of Wildlife, Arcata, California, USA.

Grenier, J. J., and S. K. Nelson. 1995. Marbled Murrelet habitat associations in Oregon. Pages 191-204 in C. J. Ralph, G. L. Hunt, Jr., M. G. Raphael, and J. F. Piatt, editors. Ecology and conservation of the Marbled Murrelet. U.S. U.S. Forest Service General Technical Report PSW-GTR-152. Pacific Southwest Research Station Albany, California, USA. https://doi. org/10.5962/bhl.title.23948

Hamer, T. E. 1995. Inland habitat associations of Marbled Murrelets in Western Washington. Pages 163-175 in C. J. Ralph, G. L. Hunt, Jr., M. G. Raphael, and J. F. Piatt, editors. Ecology and conservation of the Marbled Murrelet. U.S. Forest Service General Technical Report PSW-GTR-152. Pacific Southwest Research Station Albany, California, USA. https://doi. org/10.5962/bhl.title.23948

Hamer, T. E., and S. K. Nelson. 1995. Characteristics of Marbled Murrelet nest trees and nesting stands. Pages 69-82 in C. J. Ralph, G. L. Hunt, Jr., M. G. Raphael, and J. F. Piatt, editors. Ecology and conservation of the Marbled Murrelet. U.S. Forest Service General Technical Report PSW-GTR-152. Pacific Southwest Research Station Albany, California, USA. https://doi. org/10.5962/bhl.title.23948

Hamer, T. E., D. E. Varland, T. L. McDonald, and D. Meekins. 2008. Predictive model of habitat suitability for the Marbled Murrelet in Western Washington. Journal of Wildlife Management 72:983-993. https://doi.org/10.2193/2006-565

Hawksworth, F. G., and D. Wiens. 1996. Dwarf mistletoes: biology, pathology, and systematics. Agriculture Handbook No. 709. U.S. Forest Service, Washington, D.C., USA.

Hébert, P. N., H. R. Carter, R. T. Golightly, and D. L. Orthmeyer. 2003. Radio-telemetry evidence of re-nesting in the same season by the Marbled Murrelet. Waterbirds 26:261-265. https://doi. org/10.1675/1524-4695(2003)026[0261:REORIT]2.0.CO;2

Henderson, J. A., D. H. Peter, R. D. Lesher, and D. C. Shaw. 1989. Forested plant associations of the Olympic National Forest. U.S. Forest Service General Technical Report R6-ECOL-TP 001-88.
Hoerl, A. E., and R. W. Kennard. 1970. Ridge regression: biased estimation for nonorthogonal problems. Technometrics 12:55-67. https://doi.org/10.1080/00401706.1970.10488634

Jones, P. H. 2001. The Marbled Murrelets of the Caren Range and Middlepoint Bight. Western Canada Wilderness Committee, Vancouver, British Columbia, Canada.

Keogh, R. H., and D. R. Cox. 2014. Case-control studies. Volume 4. Cambridge University Press, Cambridge, UK. https://doi. org/10.1017/CBO9781139094757

Manley, I. A. 1999. Behaviour and habitat selection of Marbled Murrelets nesting on the Sunshine Coast. Thesis. Simon Fraser University, Burnaby, British Columbia, Canada.

McShane, C., T. Hamer, H. Carter, G. Swartzman, V. Friesen, D. Ainley, R. Tressler, K. Nelson, A. Burger, L. Spear, T. Mohagen, R. Martin, L. Henkel, K. Prindle, C. Strong, and J. Keany. 2004. Evaluation report for the 5-year status review of the Marbled Murrelet in Washington, Oregon and California. Prepared for the U.S. Fish and Wildlife Service, Region 1, Portland, Oregon. EDAW Inc., Seattle, Washington, USA.

Meyer, C. B., S. L. Miller, and C. J. Ralph. 2004. Stand-scale habitat associations across a large geographic region of an oldgrowth specialist, the Marbled Murrelet. Wilson Bulletin 116:197-210. http://dx.doi.org/10.1676/03-122

Miller, S. L., and C. J. Ralph. 1995. Relationship of Marbled Murrelets with habitat characteristics at inland sites in California. Pages 205-218 in C. J. Ralph, G. L. Hunt, Jr., M. G. Raphael, and J. F. Piatt, editors. Ecology and conservation of the Marbled Murrelet. U.S. U.S. Forest Service General Technical Report PSW-GTR-152. Pacific Southwest Research Station Albany, California, USA. https://doi.org/10.5962/bhl.title.23948

Naslund, N. L., K. J. Kuletz, M. Cody, and D. Marks. 1993. Tree and habitat characteristics and behavior at 14 Marbled Murrelet tree nests in Alaska. Pacific Seabird Group Bulletin 20:41.

Naslund, N. L., K. J. Kuletz, M. B. Cody, and D. K. Marks. 1995. Tree and habitat characteristics and reproductive success at Marbled Murrelet tree nests in Alaska. Northwestern Naturalist 76:12-25. https://doi.org/10.2307/3536739

Nelson, S. K. 2020. Marbled Murrelet (Brachyramphus marmoratus), version 1.0. In A. F. Poole and F. B. Gill, editors. Birds of the World. Cornell Lab of Ornithology, Ithaca, New York, USA. https://doi.org/10.2173/bow.marmur.01

Nelson, S. K., and T. E. Hamer. 1995a. Nesting biology and behavior of the Marbled Murrelet. Pages 57-68 in C. J. Ralph, G. L. Hunt, Jr., M. G. Raphael, and J. F. Piatt, editors. Ecology and conservation of the Marbled Murrelet. U.S. U.S. Forest Service General Technical Report PSW-GTR-152. Pacific Southwest Research Station Albany, California, USA. https://doi. org/10.5962/bhl.title. 23948

Nelson, S. K., and T. E. Hamer. 1995b. Nest success and the effects of predation on Marbled Murrelets. Pages 89-98 in C. J. Ralph, G. L. Hunt, Jr., M. G. Raphael, and J. F. Piatt, editors. Ecology and conservation of the Marbled Murrelet. U.S. U.S. Forest Service General Technical Report PSW-GTR-152. Pacific 
Southwest Research Station Albany, California, USA. https://doi. org/10.5962/bhl.title. 23948

Nelson, S. K., M. H. Huff, S. L. Miller, and M. G. Raphael. 2006. Marbled Murrelet biology: habitat relations and populations. Pages 9-30 in M. H. Huff, M. G. Raphael, S. L. Miller, S. K. Nelson, and J. Baldwin, editors. Northwest forest plan-the first 10 years (1994-2003): status and trends of populations and nesting habitat for the Marbled Murrelet. General Technical Report PNW-GTR-650. U.S. Forest Service, Pacific Northwest Research Station, Portland, Oregon, USA. https://doi.org/10.2737/pnwgtr-650

Nelson, S. K., and R. W. Peck. 1995. Behavior of marbled murrelets at nine nest sites in Oregon. Northwestern Naturalist 76:43-53. https://doi.org/10.2307/3536744

Nelson, S. K., and A. K. Wilson. 2002. Marbled Murrelet habitat characteristics on state lands in western Oregon. Oregon Department of Forestry and Oregon Department of Fish and Wildlife, Salem, Oregon, U.S. Fish and Wildlife Service, Portland, Oregon, and NCASI, Corvallis, Oregon, USA.

Norris, D. R., P. Arcese, D. Preikshot, D. F. Bertram, and T. K. Kyser. 2007. Diet reconstruction and historic population dynamics in a threatened seabird. Journal of Applied Ecology 44:875-884. https://doi.org/10.1111/j.1365-2664.2007.01329.x

Peery, M. Z., S. R. Beissinger, S. H. Newman, E. B. Burkett, and T. D. Williams. 2004. Applying the declining population paradigm: diagnosing causes of poor reproduction in the Marbled Murrelet. Conservation Biology 18:1088-1098. https:// doi.org/10.1111/j.1523-1739.2004.00134.x

Perry, D. R. 1978. A method of access into the crowns of emergent and canopy trees. Biotropica 10:155-157. https://doi. org/10.2307/2388019

Plummer, M. 2003. JAGS: A program for analysis of Bayesian graphical models using Gibbs sampling. Proceedings of the 3rd International Workshop on Distributed Statistical Computing 124:125. Technische University at Wien, Austria. [online] URL: http://www.ci.tuwien.ac.at/Conferences/DSC-2003/Drafts/Plummer. pdf

R Development Core Team. 2019. R: A language and environment for statistical computing. $\mathrm{R}$ Foundation for Statistical Computing, Vienna, Austria. [online] URL: http:// www.R-project.org/

Raphael, M. G., G. A. Falxa, K. M. Dugger, B. M. Galleher, D. Lynch, S. L. Miller, S. K. Nelson, and R. D. Young. 2011. Northwest forest plan - the first 15 years (1994-2008): status and trend of nesting habitat for the Marbled Murrelet. U.S. Forest Service General Technical Report PNW-GTR-848. Pacific Northwest Research Station, Olympia, Washington, USA. https://doi.org/10.2737/pnw-gtr-848

Recovery Implementation Team (RIT). 2012. Report on Marbled Murrelet recovery implementation team meeting and stakeholder workshop. U.S. Fish and Wildlife Service, Washington Fish and Wildlife Office, Lacey, Washington, USA.
Silvergieter, M. P., and D. B. Lank. 2011a. Patch scale nest-site selection by Marbled Murrelets (Brachyramphus marmoratus). Avian Conservation and Ecology 6(2):6. https://doi.org/10.5751/ ace-00483-060206

Silvergieter, M. P., and D. B. Lank. 2011b. Marbled Murrelets select distinctive nest trees within old-growth forest patches. Avian Conservation Ecology 6(2):3. https://doi.org/10.5751/ace-00462-060203

Singer, S. W., D. L. Suddjian, and S. A. Singer. 1995. Fledging behavior, flight patterns, and forest characteristics at Marbled Murrelet tree nests in California. Northwestern Naturalist 76:54-62. https://doi.org/10.2307/3536745

Su, Y., and M. Yajima. 2015. R2jags: Using R to Run 'JAGS'. R package version 0.5-7. http://CRAN.R-project.org/package= R2jags.

U.S. Fish and Wildlife Service (USFWS). 1992. Endangered and threatened wildlife and plants; determination of threatened status for the Washington, Oregon, and California population of the Marbled Murrelet. Federal Register 57(191):45328-45337.

U.S. Fish and Wildlife Service (USFWS). 1997. Recovery plan for the Marbled Murrelet (Brachyramphus marmoratus) in Washington, Oregon, and California. USFWS Region 1, Portland, Oregon, USA.

U.S. Fish and Wildlife Service(USFWS). 2009. Marbled Murrelet (Brachyramphus marmoratus): 5-year review. U.S. Fish and Wildlife Service, Washington Fish and Wildlife Office, Lacey, Washington.

Valente, J. J., S. K. Nelson, J. W. Rivers, D. D. Roby, and M. G. Betts. 2021. Experimental evidence that social information affects habitat selection in Marbled Murrelets. Ornithology 138(2): ukaa086. https://doi.org/10.1093/ornithology/ukaa086

van Rooyen, J. C., J. Malt, and D. Lank. 2011. Relating microclimate to epiphyte availability: edge effects on nesting habitat availability for the Marbled Murrelet. Northwest Science 85(4):549-561. https://doi.org/10.3955/046.085.0405

Waterhouse, F. L., R. Bradley, J. Markila, F. Cooke, and L. Lougheed. 2002. Use of airphotos to identify, describe and manage forest structure of Marbled Murrelet nesting habitat at a coastal British Columbia site. Technical Report TR-016. Research Section, Vancouver Forest Region, BC Ministry of Forests, Nanaimo, British Columbia, Canada.

Waterhouse, F. L., A. E. Burger, D. B. Lank, P. K. Ott, E. A. Krebs, and N. Parker. 2009. Using the low-level aerial survey method to identify Marbled Murrelet nesting habitat. Journal of Ecosystems and Management 10:80-96. [online] URL: https:// jem-online.org/index.php/jem/article/view/413

Waterhouse, F. L., A. Donaldson, P. K. Ott, and G. Kaiser. 2011. Interpretation of habitat quality from air photos at Marbled Murrelet nest sites in Mussel Inlet on the British Columbia Central Coast. Technical Report 061. B.C. Ministry of Forests, Mines Lands, Victoria, British Columbia, Canada. [online] URL: https://www.for.gov.bc.ca/hfd/pubs/Docs/Tr/Tr061.htm 
Wilk, R. J., M. G. Raphael, and T. D. Bloxton, Jr. 2016. Nesting habitat characteristics of Marbled Murrelets occurring in nearshore waters of the Olympic Peninsula, Washington. Journal of Field Ornithology 87:162-175. https://doi.org/10.1111/jofo. 12150

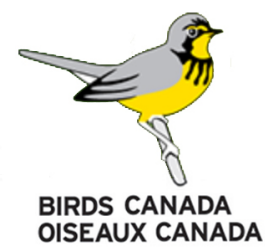

